\title{
EFEKTIVITAS PENGGUNAAAN MEDIA GAMBAR PERISTIWA ALAM \\ TERHADAP KEMAMPUAN MENULIS TEKS EKSPLANASI SISWA \\ KELAS VII SMP NEGERI 2 SIDIKALANG
}

TAHUN PEMBELAJARAN 2016/2017

\author{
Marta Ulina Bancin \\ martabancin123@gmail.com
}

Prof. Dr. Biner Ambarita, M.Pd.

Penelitian ini bertujuan untuk mengetahui efektivitas media gambar peristiwa alam terhadap kemampuan menulis teks eksplanasi siswa kelas VII SMP Negeri 2 Sidikalang. Penelitian ini menggunakan penelitian eksperimen. Desain penelitian yang digunakan adalah one group pre-test post-test design yaitu model eksperimen semu yang melibatkan perlakuan berbeda terhadap satu kelas yang sama. Populasi penelitian ini adalah seluruh siswa kelas VII SMP Negeri 2 Sidikalang tahun pembelajaran 2016/2017 yang berjumlah 208 siswa dan yang menjadi sampel penelitian sebanyak 33 siswa, yakni kelas VII-4 untuk kelas pre-test dan post-test. Pengambilan sampel ini dilakukan dengan menggunakan teknik random sampling. Instrumen atau alat pengumpulan data yang digunakan adalah tes esai. Berdasarkan hasil pengolahan data yang diperoleh, data pre-test memperoleh rata-rata sebesar 63,33 dan standar deviasi sebesar 8,03 sedangkan data post-test memperoleh rata-rata 76,81dan standar deviasi sebesar 6,83. Pengujian hipotesis dilakukan dengan menggunakan uji " $\mathrm{t}$ ". Dari perhitungan uji hipotesis diperoleh thitung $=7,10$ selanjutnya diperoleh ttabel pada taraf signifikan $5 \%=2,03$. Kriteria pengujian adalah jika harga thitung > ttabel atau $7,10>2,03$ hal ini menunjukkan bahwa hipotesis nihil (Ho) ditolak dan hipotesis alternatif (Ha) diterima yang berarti media gambar efektiv digunakan terhadap kemampuan menulis teks eksplanasi.

Kata Kunci: Media gambar, menulis teks eksplanasi 


\section{PENDAHULUAN}

Bahasa merupakan alat komunikasi yang digunakan seseorang untuk berinteraksi dan berkomunikasi dengan orang lain. Komunikasi dapat dilakukan secara lisan dan tulisan, komunikasi secara tulisan berarti harus diawali dengan aktivitas menulis. Semi (2007:41) menyatakan "menulis berarti suatu proses kreatif, menulis juga merupakan sebuah keterampilan yang dilakukan melalui tahapan yang harus dikerjakan dengan mengerahkan keterampilan seni, dan kiat sehingga semuanya berjalan dengan efektif'.

\section{Kurikulum}

pembelajaran bahasa Indonesia sudah menggunakan pendekatan berbasis teks. Teks merupakan ungkapan pikiran manusia yang lengkap yang di dalamnya memiliki situasi dan konteks. Hal ini bertujuan agar siswa tidak hanya sekedar belajar pengetahuan bahasa saja melainkan dapat mengembangkan kemampuan menalar siswa dalam bentuk lisan maupun tulisan. Pendekatan berbasis teks lebih menekankan siswa pada kegiatan menulis.

$$
\text { Pembelajaran Bahasa }
$$

Indonesia dalam Kurikulum 2013 melingkupi seluruh pengetahuan melalui teks-teks yang telah disajikan dalam buku ajar dan buku pedoman siswa. Salah satu pembelajaran menulis teks pada pembelajaran Bahasa Indonesia yaitu pembelajaran menulis teks eksplanasi yang dimuat dalam kurikulum 2013 di kelas VII SMP. Teks eksplanasi ini merupakan jenis teks yang menjelaskan hubungan logis dari beberapa peristiwa. Teks eksplanasi merupakan teks yang menerangkan atau menjelaskan tentang proses yang berhubungan dengan fenomena alam, pengetahuan ataupun sosial. Menurut Priyatni (2014:82) menyatakan "teks eksplanasi bertujuan untuk menjelaskan proses pembentukan atau kegiatan yang terkait dengan fenomena alam, sosial, ilmu pengetahuan atau budaya”.

Keterampilan menulis di sekolah juga masih sangat rendah. Beberapa jurnal penelitian 
menjelaskan mengenai keterampilan menulis siswa di sekolah. Desy Maria berpendapat bahwa terdapat permasalahan dalam pembelajaran menulis teks eksplanasi siswa antara lain (1) ide yang disampaikan meloncat-loncat, (2) stuktur bahasa tidak teratur, (3) diksi bercampur dengan bahasa ibu, (4) ejaan dan tanda baca diabaikan, dan (5) tulisan belum orisinal. Selain itu, Pestauli mengatakan $65 \%$ siswa memperoleh nilai $\leq 70$ sedangkan $\mathrm{KKM}$ untuk menulis

teks eksplanasi adalah 75 . Rendahnya kemampuan siswa dalam menulis teks eksplanasi disebabkan karena siswa kurang termotivasi. Hal ini mengakibatkan kemampuan siswa untuk mengembangkan ide dalam bentuk tulisan masih rendah sehingga siswa menganggap menulis itu membosankan. Selain hal tersebut, siswa kurang berminat menulis disebabkan karena model yang digunakan guru kurang bervariasi sehingga hasil belajar siswa dalam praktik menulis teks eksplanasi belum maksimal.
Sebelumnya peneliti juga telah melakukan wawancara dengan salah satu guru bahasa Indonesia di SMP Negeri 2 Sidikalang, yaitu Ibu Ratna Tarigan S.Pd pada hari Selasa 2 Februari 2017 menyatakan banyak siswa yang sulit menuangkan ide atau gagasan dalam menulis teks eksplanasi, dan belum memahami tentang kaidah mengarang yang baik, serta minimnya kosakata yang dikuasai.

Langkah untuk meningkatkan kemampuan siswa dalam menulis teks eksplanasi, adalah dengan menggunakan media yang tepat yang mampu merangsang keterampilan siswa dalam menulis. Salah satu media pembelajaran yang dapat meningkatkan kemampuan menulis khususnya teks eksplanasi adalah media gambar.

Sadiman

(2003:21), menyatakan media gambar adalah suatu gambar yang berkaitan dengan materi pelajaran yang berfungsi untuk menyampaikan pesan dari guru kepada siswa. Media gambar ini dapat membantu siswa untuk mengungkapkan informasi yang 
terkandung dalam masalah sehingga hubungan antar komponen dalam masalah tersebut dapat terlihat dengan lebih jelas.

\section{Pembelajaran dengan}

menggunakan media gambar dapat menarik perhatian siswa mengikuti proses belajar mengajar dikarena media gambar memiliki warna sehingga tampak lebih realitas dan merangsang minat siswa untuk mengamatinya. Selain itu, penggunaan media gambar juga dapat mengatasi kesulitan siswa dalam menemukan ide dan mengembangkan idenya dalam bentuk komentar atau pendapat. Melalui gambar, siswa seolah-olah dapat melihat langsung peristiwa yang ada di dalam gambar.

\section{Mahsun} berpendapat bahwa "Teks eksplanasi memiliki fungsi sosial menjelaskan atau menganalisis proses muncul atau terjadinya sesuatu." Sejalan dengan itu menurut Priyatni (2014:82) mengatakan teks eksplanasi adalah "Teks yang berisi penjelasan tentang proses yang berhubungan dengan fenomena- fenomena alam, sosial, ilmu pengetahuan, dan budaya." Berdasarkan pendapat di atas disimpulkan bahwa teks eksplanasi merupakan penjelasan tentang proses-proses terjadinya fenomenafenomena alam, sosial, ilmu pengetahuan dan budaya yang menjelaskan hubungan logis, teks ini juga merupakan produk tulisan yang dihasilkan dengan memperhatikan, menafsirkan, dan membahas fenomena-fenomena alam, sosial, ilmu pengetahuan dan budaya. Kokasih (2014:178) juga berpendapat karakteristik teks eksplanasi adalah teks ini biasa memuat informasi-informasi fakta, membahas suatu fenomena yang berisifat keilmuan atau ilmu pengetahuan, bersifat infomatif dan tidak berusaha mempengaruhi pembaca untuk mempercayai hal yang dibahas di dalam teks, dan memiliki atau menggunakan sequence markers (tanda urutan).

Teks eksplanasi memiliki struktur yang membangun teks tersebut. Struktur dalam penulisan teks eksplanasi adalah judul, 
menjelaskan/menginformasikan

tentang sesuatu fenomena atau

peristiwa, Pernyataan umum

memuat petunjuk awal tentang suatu

peristiwa/fenomena yang hendak

dijelaskan, Rincian penjelas memuat tentang bagaimana atau mengapa suatu peristiwa/fenomena terjadi, Simpulan berupa pengulangan informasi penting atau kata penutup yang menandai bahwa penjelasan telak berakhir.

Berdasarkan uraian di atas, maka peneliti tertarik untuk melakukan penelitian yang berjudul "Efektivitas Penggunaan Media Gambar Peristiwa AlamTerhadap Kemampuan Menulis Teks Eksplanasi Siswa Kelas VII SMP Negeri 2 Sidikalang Tahun Pelajaran 2016/2017'.

\section{METODE PENELITIAN}

Metode penelitian merupakan hal yang penting dalam pelaksanaan penelitian. Metode penelitian diharapkan dapat menjawab setiap permasalahan yang ada. Sebab berhasil tidaknya suatu penelitian sangat ditentukan oleh metode yang digunakan. Oleh karena itu, diperlukan metode penelitian yang tepat sesuai dengan tujuan penelitian ini.

$\begin{array}{lrr} & & \text { Metode yang } \\ \text { dianggap tepat digunakan dalam } & \\ \text { penelitian ini adalah metode } \\ \text { eksperimen semu. Eksperimen }\end{array}$
dilakukan adalah untuk melihat akibat dari suatu perlakuan. Hal ini sesuai dengan pendapat Sugiyono (2009:11) yang menyatakan, "Metode penelitian eksperimen semu merupakan metode penelitian yang digunakan untuk mencari pengaruh treatment (perlakuan) tertentu."

Desain penelitian ini adalah one group pre-test post-test design. Arikunto (2006:12) berpendapat bahwa, "One group pre-test post-test design adalah eksperimen yang dilaksanakan pada suatu kelompok saja tanpa kelompok pembanding." Desain model ini memberikan perlakuan yang sama pada setiap subjek tanpa memperhitungkan dasar kemampuan yang dimiliki. Meskipun terdapat kemungkinan masingmasing subjek sampel memiliki kemampuan dasar yang berbedabeda. Siswa yang menjadi sampel 
dalam penelitian ini akan mendapatkan hal yang sama yaitu tes awal (pre-test), perlakuan dengan menggunakan media gambar dalam pembelajarannya, dan tes akhir (posttest).

\section{HASIL DAN PEMBAHASAN PENELITIAN}

\section{Hasil Penelitian}

\section{a. Kemampuan Menulis Teks} Eksplanasi Sebelum Menggunakan

\section{Media Gambar}

Hasil nilai rata-rata atau mean secara keseluruhan yang diperoleh siswa dalam menulis teks eksplanasi sebelum menggunakan media gambar adalah sebesar 63,33 dengan kategori cukup. Skor terendah dalam menulis teks

eksplanasi sebelum menggunakan media gambar adalah sebesar 65 dan skor tertinggi dalam menulis teks eksplanasi sebelum menggunakan media gambar adalah sebesar 90 .

Hasil pre-test kemampuan menulis teks eksplanasi sebelum menggunakan media gambar dapat dikategorikan menjadi empat kategori yaitu kategori sangat baik sebanyak 0 siswa atau 0\%, kategori baik sebanyak 4 siswa atau 12,12\%, kategori cukup sebanyak 15 siswa atau 45,45\%, kategori kurang sebanyak 10 siswa atau 30,30\% dan kategori sangat kurang sebanyak 4 siswa atau $12,12 \%$.

\section{b. Kemampuan Menulis Teks} Eksplanasi Sesudah Menggunakan Media Gambar

Hasil nilai rata-rata atau mean secara keseluruhan yang diperoleh siswa dalam menulis teks eksplanasi sesudah menggunakan media gambar adalah sebesar 76,81 dengan kategori baik. Skor terendah dalam menulis teks eksplanasi sesudah menggunakan media gambar adalah sebesar 60 dan skor tertinggi dalam menulis teks eksplanasi sesudah menggunakan media gambar adalah sebesar 90 .

Hasil post-test kemampuan menulis teks eksplanasi sesudah menggunakan media gambar dapat dikategorikan menjadi empat kategori yaitu sangat baik, baik, cukup dan kurang. Setelah diidentifikasi, maka didapatlah siswa 
yang berada pada kategori sangat baik sebanyak 9 siswa atau 27,27\%, kategori baik sebanyak 14 siswa atau 42,42\%, kategori cukup sebanyak 10 siswa atau 30,30\%, kategori kurang sebanyak 0 siswa atau $0 \%$ dan kategori sangat kurang sebanyak 0 siswa atau $0 \%$.

\section{c. Efektivitas media gambar} terhadap kemampuan menulis teks eksplanasi siswa kelas VII SMP

\section{Negeri 2 Sidikalang Tahun}

\section{Pembelajaran 2016/2017}

Setelah melakukan penelitian dan mendapatkan data yang sudah dianalisis, maka ada perbedaan kemampuan menulis teks eksplanasi sebelum menggunakan media gambar dengan sesudah menggunakan media gambar. Ini membuktikan bahwa media gambar efektif digunakan dalam menulis teks eksplanasi.

Hal di atas dapat dilihat dengan nilai rata-rata siswa dalam menulis teks eksplanasi sebelum menggunakan media gambar sebesar 63,33 dengan standar deviasi sebesar 8,03 sedangkan sesudah diberikan media gambar, kemampuan siswa dalam menulis teks eksplanasi meningkat dengan nilai rata-rata sebesar 76,8 dengan standar deviasi sebesar 6,83. Dengan demikian, dapat disimpulkan bahwa media gambar efektif dalam meningkat kemampuan menulis teks eksplanasi siswa kelas VII SMP Negeri 2 Sidikalang Tahun Pembelajaran 2016/2017.

\section{Pembahasan Hasil Penelitian}

Setelah melakukan prosedur penelitian seperti uji normalitas, homogenitas, dan uji hipotesis, akhiranya dapat ditemukan hasil dari penelitian. Media gambar yang digunakan untuk meningkatkan kemampuan menulis teks eksplanasi siswa kelas VII SMP Negeri 2 Sidikalang tahun pembelajaran 2016/2017 efektif digunakan terhadap hasil belajar. Hal tersebut dibuktikan dari hasil pre-test dan post-test siswa yang menjadi sampel pada penelitian ini. Berdasarkan perhitungan yang telah dilakukan, dapat diketahui bahwa rata-rata siswa sebelum menggunakan media gambar lebih rendah dibandingkan 
dengan nilai rata-rata siswa sesudah menggunakan media gambar.

\section{a. Kemampuan Menulis Teks} Eksplanasi Sebelum Menggunakan Media Gambar

Kemampuan menulis teks eksplanasi siswa kelas VII SMP Negeri 2 Sidikalang Tahun Pembelajaran 2016/2017 sebelum menggunakan media gambar berada pada kategori cukup. Hal ini dapat dilihat dari nilai rata-rata sebesar 63,33 . Siswa yang mendapat nilai baik sebanyak 4 siswa atau $12,12 \%$, nilai cukup sebanyak 15 siswa atau $45,45 \%$, nilai sangat kurang sebanyak 10 siswa atau 30,30\% dan kategori sangat kurang sebanyak 4 siswa atau $12,12 \%$. Hasil nilai pretest menunjukkan bahwa kemampuan siswa dalam menulis teks eksplanasi sebelum menggunakan media gambar termasuk pada kategori kurang.

b. Kemampuan Menulis Teks Eksplanasi Sesudah Menggunakan Media Gambar
Kemampuan menulis teks eksplanasi oleh siswa kelas VII SMP Negeri 2 Sidikalang Tahun Pembelajaran 2016/2017 sesudah menggunakan media gambar mengalami peningkatan. Hal tersebut dapat dilihat dari nilia rata-rata sebesar 76,81 . Siswa yang mendapat nilai sangat baik sebanyak 9 siswa atau $27,27 \%$, kategori baik sebanyak 14 siswa atau 42,42\%, kategori cukup sebanyak 10 siswa atau 30,30\%, Hasil nilai post-test menunjukkan bahwa kemampuan siswa dalam menulis teks eksplanasi setelah menggunakan media gambar termasuk pada kategori baik. Melalui media gambar, siswa seolah-olah dapat melihat langsung peristiwa yang ada dalam gambar. Hal ini memungkinkan siswa lebih cepat dan mudah menemukan dan menuangkan ide tersebut dalam bentuk tulisan, sehingga siswa tidak lagi mengalami kesulitan dalam mengungkapkan kata-kata. Dengan menggunakan media gambar kegiatan menulis siswa menjadi lebih mudah.

Peningkatan nilai siswa sesudah menggunakan media gambar dapat terjadi karena media tersebut 
menarik minat siswa untuk belajar. Media gambar memiliki warna sehingga tampak lebih nyata dan mampu merangsang minat siswa untuk mengamatinya. Media pembelajaran yang bersifat visual sangat membantu siswa dalam proses belajar khususnya dalam pembelajaran menulis teks eksplanasi, sebab dapat mengatasi kesulitan dalam menemukan dan mengembangkan tulisannya. Media pembelajaran ini sangat cocok untuk pembelajaran menulis teks eksplanasi.

\section{c. Efektivitas media gambar} terhadap kemampuan menulis teks eksplanasi siswa kelas VII SMP Negeri 2 Sidikalang Tahun Pembelajaran 2016/2017

Data hasil penelitian
menunjukkan adanya perbedaan
kemampuan menulis teks eksplanasi
sebelum menggunakan media
gambar dengan sesudah

menggunakan media gambar yang membuktikan bahwa media gambar efektif digunakan dalam menulis teks eksplanasi.

Hal di atas dapat dilihat dengan nilai rata-rata siswa dalam menulis teks eksplanasi sebelum menggunakan media gambar sebesar 63,33 dengan standar deviasi sebesar 8,03 sedangkan sesudah diberikan media gambar, kemampuan siswa dalam menulis teks eksplanasi meningkat dengan nilai rata-rata sebesar 76,8 dengan standar deviasi sebesar 6,83. Berdasarkan aspek penilaian menulis teks eksplanasi, yang menjadi kriteria penilaian adalah kemampuan menuliskan teks eksplanasi yaitu isi, struktur, kalimat, kosakata dan mekanik. Data kemampuan menulis teks eksplanasi sebelum menggunakan media gambar pada aspek penilaian yang memiliki rata-rata tertinggi pada aspek penilaian isi, yaitu sebesar $14,39 \%$. Kriteria penilaian yang memiliki nilai rata-rata terendah ada pada aspek penilaian mekanik yaitu sebesar 10,75\%. Sedangkan, data 
kemampuan menulis teks eksplanasi sesudah menggunakan media gambar pada aspek penilaian yang memiliki rata-rata tertinggi ada pada kemampuan menulis isi, yaitu sebesar 17,27. Kriteria penilaian yang memiliki nilai rata-rata terendah ada pada aspek penilaian mekanik yaitu sebesar 13,48\%.

Aspek penilaian mekanik yang dilihat dari penulisan tanda baca, huruf kapital, ejaan, penataan paragraf sangat penting diperhatikan dalam menulis agar tidak terjadi kerancuan arti. Dalam data pre-test (sebelum perlakuan) memiliki ratarata 10,75 dengan 5 siswa memperoleh skor 15 dan 28 siswa memperoleh skor 10. Dalam hal ini pemahaman mekanik siswa masih rendah sehingga menimbulkan banyak kesalahan dalam menulis. Sedangkan dalam data post-test memiliki nilai rata-rata 13,48 dengan 23 siswa memperoleh skor 15 dan 10 siswa memperoleh skor 10. Dalam hal ini terjadi peningkatan 2,7 selisih rata-rata setelah menerapkan media gambar sebagai media pembelajaran, namun pemahaman siswa tentang mekanik lebih banyak dijelaskan oleh guru.

Berdasarkan hasil penelitian dan pembahasan, maka dapat disimpulkan bahwa penggunaan media gambar efektif digunakan terhadap kemampuan menulis teks eksplanasi siswa kelas VII SMP Negeri 2 Sidikalang Tahun Pembelajaran 2016/2017.

\section{PENUTUP}

Berdasarkan hasil dan pembahasan penelitian ini, maka dapat disimpulkan beberapa hal sebagai berikut :

1. Kemampuan siswa dalam menulis teks eksplanasi sebelum menggunakan media gambar termasuk dalam kategori cukup. Hal itu terbukti dengan nilai rata-rata siswa yakni 63,33.

2. Kemampuan siswa dalam menulis teks eksplanasi sesudah menggunakan media gambar termasuk dalam kategori baik. Hal itu terbukti dengan nilai rata-rata siswa yakni 76,81. 
3. Penggunaan media gambar lebih efektif terhadap kemampuan menulis teks eksplanasi siswa kelas VII SMP Negeri 2 Sidikalang Tahun Pembelajaran 2016/2017. Hal itu terbukti dengan uji " $\mathrm{t}$ " yaitu

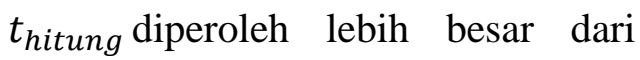
$t_{\text {tabel }}$ yaitu 7,03 > 2,04 dengan kata lain Ho ditolak dan Ha diterima.

\section{DAFTAR PUSTAKA}

Arikunto, Suharsimi. 2006. Prosedur Penelitian Suatu Pendekatan Praktik. Jakarta : Rineka Cipta.

Desy Maria. "Peningkatan Keterampilan Menulis Teks Eksplanasi Siswa Kelas VII E SMP Negeri 1 Situbondo Dengan Teknik Konsep Kalimat" NOSI Volume 3 Nomor 3. 2015.

Kokasih, E. 2014. Jenis-jenis Teks. Bandung: Yrama Widya

Mahsun. 2014. Teks dalam Pembelajaran Bahasa Indonesia (Kurikulum 2013). Jakarta: PT Raja Grafindo Persada.

Pestauli, 2014. Pengaruh Penerapan Model Pembelajaran Berbasis Masalah Terhadap Kemampuan Menulis Teks Eksplanasi Siswa Kelas VII SMP Santo Ignasius Medan Tahun
Pembelajaran 2013/2014. Medan: Universitas Negeri Medan, Volume 3 Nomor 4. 2014.

Priyatni, Endah Tri. 2014. Desain Pembelajaran Bahasa Indonesia dalam Kurikulum 2013. Jakarta : Bumi Aksara.Sadiman, Arief. dkk. 2010. Media Pendidikan. Jakarta: Rajawali Pers.

Sadiman, Arif.dkk. 2003. Media Pendidikan. Jakarta: Rajawali Pres.

Semi, M. 2007. Dasar-dasar Keterampilan Menulis. Bandung: Angkasa.

Sugiyono.2009. Metode Penelitian Kuantitatif Kualitatif dan $R \& D$. Bandung : Alfabeta. 